IRA-International Journal of Education \& Multidisciplinary Studies

ISSN 2455-2526; Vol.03, Issue 03 (2016)

Institute of Research Advances

http://research-advances.org/index.php/IJEMS

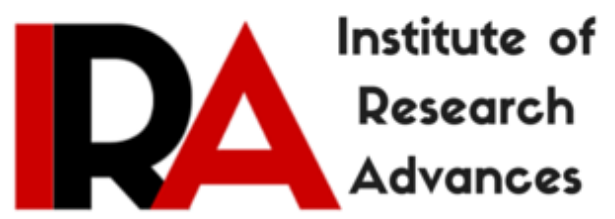

\title{
Implementation of Internship in 2 Year B.Ed. Course - A Challenge or Routine Task
}

Dr. Parijat Chakrabarty

Associate Professor, West Guwahati College of Education, Templeghat, Pandu, Guwahati-12, India.

DOI: http://dx.doi.org/10.21013/jems.v3.n3.p18

\section{How to cite this paper:}

Chakrabarty, D. (2016). Implementation of Internship in 2 Year B.Ed. Course - A Challenge or Routine Task. IRA International Journal of Education and Multidisciplinary Studies (ISSN 2455-2526), 3(3). doi:http://dx.doi.org/10.21013/jems.v3.n3.p18

(C) Institute of Research Advances

\section{(c)) EY-NC}

This works is licensed under a Creative Commons Attribution-Non Commercial 4.0 International License subject to proper citation to the publication source of the work.

Disclaimer: The scholarly papers as reviewed and published by the Institute of Research Advances (IRA) are the views and opinions of their respective authors and are not the views or opinions of the IRA. The IRA disclaims of any harm or loss caused due to the published content to any party. 
In the recent years all over India there has been a drastic change in B.Ed. course. The switch over to one year course to two year B.Ed. course is quite interesting and challenging task. Any teacher education course seeks to train teacher having requisite teaching skills. Practicum approach adopted in the modern teacher education course is to place a student teacher in a classroom situation under the supervision of a qualified teacher. The concept of Internship introduced in the two year B.Ed. course throughout the country is quite challenging one for all the teacher education institutions. The aim of internship program is to incorporate teaching skills among the student teachers. Internship program is an effective way to give training to the student-teachers about real world of work. It give them an opportunity to integrate theory and practice, plan and deliver lessons properly, critically analyze their own and peers teaching styles and improve them in the light of feedback given by supervisors. Through this program they understand the role and responsibilities of professional teachers. Internship program also give them opportunity to understand different aspects of school program and improve their skills and abilities in teaching profession. An effective and improved internship program is required in developing student-teachers personalities as true professionals in field of education.

Teacher Education is being made Work Based Learning (WBL) programmes which seem to be encouraged and practised world-wide offering students' practical experience in their chosen field of study. Study carried out by Hanney (2005) recommends that students completing foundation or undergraduate degrees experience WBL. Hanney describes WBL as a practice where practical work is often required to mirror professional practice and students are expected to develop the kind of key transferable skills sought by employers such as communication, team working and problem solving. WBL is known as experiential learning, covering an umbrella of variety of models such as apprenticeships, cooperative education, internships, service learning, 'sandwich' placements, shadowing and externships designed to promote student learning outside of the traditional classroom model (Linn 1999). WBL or time of internship is critical in a fast-changing world where student teachers find they need to qualify with academic knowledge and be skilled to manage their own careers. In order for this practical WBL to be effective it should take place in a real world environment and be of sufficient duration for the individual to be able to demonstrate competency against learning outcomes (Skillset Foundation Degree Frameworks, 2004).

\section{Concept of Internship}

According to the University of Wisconsin-Madison (www.wisc.edu/), an internship is a Work Based Learning experience that involves on-the-job training to prepare for a future career in a given field, with the emphasis being placed on the development of skills and knowledge pertaining to that particular field of work. A student-teacher intern is expected to gain experience and knowledge and develop vital teaching skills.

Stretch and Harp (1991) states that an internship is "A supervised discipline-related work experience; Controlled experiential learning where a student receives academic credit while employed by an organisation in a chosen area of interest; A quality work experience, guided and managed by an experienced supervisor, in a position with duties that the student has not previously performed, which will benefit the student in her or his future career goals". An internship is a formal arrangement designed to provide opportunities for students to study and experience professional career interests in the community.

In 1906, Herman Schneider, a University of Cincinnati engineering professor and dean, founded cooperative education or internships because he recognised that most 
students need and want to work while attending college and the practical benefits of internships enhanced the entire learning experience (Linn, Howard and Miller 2004).

Internship may be of two types - work experience type and dissertation type. In the first type, during the second year the student teachers need to transform the learnt things acquired from the teacher training institute into practice, which may vary from two months to one year. In doing so, they gain work experience. In the second type, the student teachers who are in the last year may opt for dissertation type internship. Wherein, a student teacher shall perform research form of activity for a organization. The student teachers have to select a topic and conduct an investigation and prepare a report which needs to be presented. Either of the types of internship programs is offered to the student teachers in the countries like UK, USA, Germany, France, Nether land, Pakistan, Denmark.

In India, NCERT implemented two year B.Ed. course in the four Regional Institutes of Education since 1999 as per NCTE guidelines. According to Panda "The two-year B.Ed. programme introduced by NCERT in its RIEs has certain special features/characteristics. It provides greater scope for development of sound knowledge on different areas i.e. content knowledge, knowledge on teaching-learning methodologies and knowledge on pedagogy of teaching learning among the traineeteachers. It develops a sound knowledge base for trainee-teachers in content areas, develops skills of trainee-teachers to be competent enough regarding how to transact the content materials to the students of the schools meaningfully. Some of the value related objectives that two-year B.Ed. intends to develop among the trainee teachers are commitment, competence, accountability, dutifulness etc. of the trainee-teachers towards the profession. It intends to bring integrated development of the traineeteachers touching cognitive and non- cognitive aspects of their behaviours. It is primarily practical oriented. It gives stress on practical activities like internal assessment, project works, sessional works, internship in teaching, practice of microteaching skills, community works, practical works relating to work experiences innovative ways for conducting practical activities related to health and physical education, work experience, fieldwork with community etc."

\section{Significance of Internship}

The aim of these teacher education programmes is to train teachers to educate and teach effectively in order to facilitate learning in the classroom (Richter et al. 2004:7). Fletcher (1990:41-55) indicate that internship experiences enhance students' selfconfidence, values and attitudes and leads to an increase in student independence, social maturity and interpersonal skills. Parveen and Mirza (2012) emphasised Internship program in Teacher Education is of great significance because it ensures the professional preparation of prospective teachers. It provides them a practical opportunity to develop true understanding of the teaching profession and future prospects of working conditions in that profession.

The internship is a educational experience combining daily experiences in the classroom setting, time allocated to work on assignments and exam preparation, and time spent coaching extracurricular activities. Student-teacher interns follow the calendar of a school and work in partnership with members of the teaching staff.

A carefully planned internship program should fulfil the following aspects.

* Develop professional skills and attitudes

* Offers fruitful exposure on the job

* Understanding the nature of working climate and status

* Securing purposeful relationships with the existing human resources. 
An internship is a supervised off-campus working and learning experience, which earns academic credit. Internships give students opportunities to apply and extend the theoretical knowledge acquired in the classroom to practical experiences, while also allowing them opportunities to view and evaluate careers to which their academic interests may lead. Ideal internships establish positive contacts with prospective employers and are key to building professional networks for students (Stretch and Harp 1991:67)

In the RIEs "Two year B.Ed. trains the trainee-teachers properly to meet the multifarious problems of the school or classroom. It provides scope for pedagogical analysis of the content/ units included in its syllabus/curriculum. This pedagogical analysis becomes helpful for healthy integration of contents, methods, theories, practical, etc. for meaningful transaction. About one month pre-internship in teaching programme (during Part-1 B.Ed. stage), two-month internship in teaching programme (during Part- 11 B.Ed. stage), post-internship meet, twenty days community work programme (10 days in Part-1 \& 10 days in Part-11 B.Ed. stage) etc. are some of the special features of this course. Both the pre- internship and internship programme are supplemented by many other innovative activities like practice of micro teaching skills in simulated classroom situation, orientation of teachers of co-operative schools, multi-cultural placement, substantial field experiences, field observation, team teaching, substitute teaching, demonstration of the lessons, observation of the lessons, taught by subject teachers, preparation, use and exhibition of teaching aids, conducting action research/ case study, participation in both curricular and cocurricular activities of the school, application of skills, getting opportunities for reflection and application of their own experiences in the school situation, development of teaching learning materials, observation of school processes, taking the arrangement classes, peer group observation of teaching, analysis of school experiences etc. along with the practice teaching" (Panda).

In the internship there are a number of key persons involved out of which the role of supervisors/mentors and student teachers are the prime ones. According to McIntyre (1997) the mentor is the subject teacher who takes primary responsibility for the professional education in classroom teaching. The mentor teacher is the one who takes the student teacher into his or her classroom as a student-teacher intern. The mentor teacher guides and evaluates the lessons that the student-teacher intern presents. Anderson and Shannon (1988) refers mentoring as a nurturing process in which a skilled or more experienced person, serving as a role model, teaches, sponsors, encourages, counsels and befriends a less skilled or less experienced person for the purpose of promoting the latter's professional and/or personal development.

Roberts (2000) describe mentoring as a complex social and psychological phenomenon which cannot easily be clarified.

A student teacher intern is the one who has to practice how to prepare and teach a well-planned, good and effective lesson by learner centric and interactive methodology. Internships will also allow students to learn about time management, discipline, and effective communication skills.

\section{Internship Program \\ NCTE guidelines}

According to NCTE, two year B.Ed. curriculum states that "Having gained some experience with the child, the community and schools in Year 1, the second year would offer intensive engagement with the school in the form of School Internship. During the Internship, a student-teacher shall work as a regular teacher and participate in all the school activities, including planning, teaching and assessment, 
interacting with school teachers, community members and children. Before teaching in a classroom, the student-teachers will observe the school and its classrooms for a week, to understand the school in totality, its philosophy and aims, organisation and management; the life of a teacher; needs of the physical, mental, emotional development of children; aspects of curriculum and its transaction; quality, transaction, and assessment of teaching-learning.

School Internship shall be designed to lead to the development of a broad repertoire of perspectives, professional capacities, teacher dispositions, sensibilities and skills. Student teachers shall be equipped to cater to diverse needs of learners in schools. Student-teachers are to be actively engaged in teaching at two levels, namely, upper primary and secondary. They should be provided opportunities to teach in government and private schools with systematic supervisory support and feedback from faculty. Internship in schools is to be done for a minimum duration of 15 weeks. This should include an initial phase of one week for observing a regular classroom with a regular teacher and would also include peer observations, teacher observations and observations of interns' lessons by faculty. It is important that the studentteachers consolidate and reflect on their teaching experience during and after the school internship. Therefore, along with writing reflective journals during the internship programme, there shall be space for extended discussions and presentations on different aspects of the teaching experience after the internship. For each studentteacher, internship should be conducted preferably in one school for the entire 15 weeks. However, if the institute wants to provide an opportunity to understand the context of teaching in a government and private school or the dynamics of teaching at elementary and senior secondary levels, this period can be divided into two blocks. Internship may be arranged in two blocks in such a way that teaching in one school at a particular level (for example elementary or senior secondary) during one block, is followed by the teaching in another school or the same school at another level during the second block. Under any circumstances, the student-teacher should not be sent to more than two schools during her/his internship period. Internship should not be reduced to the 'delivery' of a certain number of lesson plans, but should aim for meaningful and holistic engagement with learners and the school. Moreover, teaching should not be practiced through the reductionist approach of 'microteaching' of isolated 'skills' and simulated lessons".

\section{Gauhati University Two Year B.Ed. Syllabus}

As per Gauhati University two years B.Ed. course comprises of 250 marks in total with the provision for internship for a period of four months. The internship scheme prescribed by Gauhati University (GU) is shown in table 1.

Table 1 Internship Scheme

\begin{tabular}{|l|l|}
\hline Activities & Marks \\
\hline $\begin{array}{l}\text { Internship (submitting monthly report on activities performed by } \\
\text { student teachers with proper certification). Student teachers should } \\
\text { remain present in respective school during the school time. }\end{array}$ & \\
\hline Preparation of scholastic achievement test cum record (Two) & $25 \times 2=50$ \\
\hline Presentation of Internship experiences and viva voice & 100 \\
\hline $\begin{array}{l}\text { InternalAssessment : 150 Marks } \\
\text { External(viva voice ): } 100 \text { Marks } \\
\text { PassMark : } \quad \text { 40\% of the total }\end{array}$ \\
\hline
\end{tabular}




\section{Implementation of Internship by the Teacher Training Institutes}

All over India, Teacher Training Institutes need to implement the internship task as per NCTE regulations. It's an upheaval task lies ahead. Work Based Learning that is the Internship has to be implemented but there are certain points which have to be tackled.

a) Obtaining permission from the Inspector of Schools for conduct of Intern in schools

b) Respective schools willingness in such type of arrangement

c) Adjustment of Student Teachers in respective schools

These are some points to be pondered upon for successful implementation of internship. The first point may not be a problem. With respect to second point, the matter is quite challenging according to my personal experience. Whether the schools will willingly accept or have to be persuasive implementation. Government or semi government schools may willingly accept but in case of private schools (if not all at least some) there is every likelihood for persuasive implementation. Because certain private schools are reluctant to offer the requisite number of classes during one/one and half month period during practice teaching session (general feeling one comes across is that school discipline, normal classes, school test, timely completion of syllabus gets hampered. So the student teachers have to be satisfied with the allotted number of classes may be $1 / 2 / 3$ days a week or two student teachers per week). If this be the situation, what will be the internship task? Will it be just be for name sake, needs to be witnessed. Coming to the third point, this needs to be thought of that whether all the student teachers will be able to adjust with new environment.

The manners in which the teacher training colleges will handle the task have to be assessed in the years to come. Implementing the task is quite challenging one and not a routine work as I perceive it. There are a number of unwanted factors which are sure to creep in and this demands serious thinking. For example, the internship task as per GU syllabus includes.

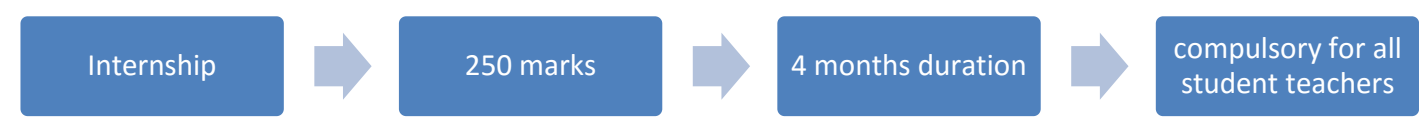

In Italy it is compulsory for almost all those students studying for a bachelor's or a master's degree to experience an internship. In the Netherlands the internship period is for approximately five months.

It follows that for successful implementation of Internship scheme, teacher training institute need to coordinate with Affiliated University, Inspector of Schools and the schools as depicted in figure 1. 


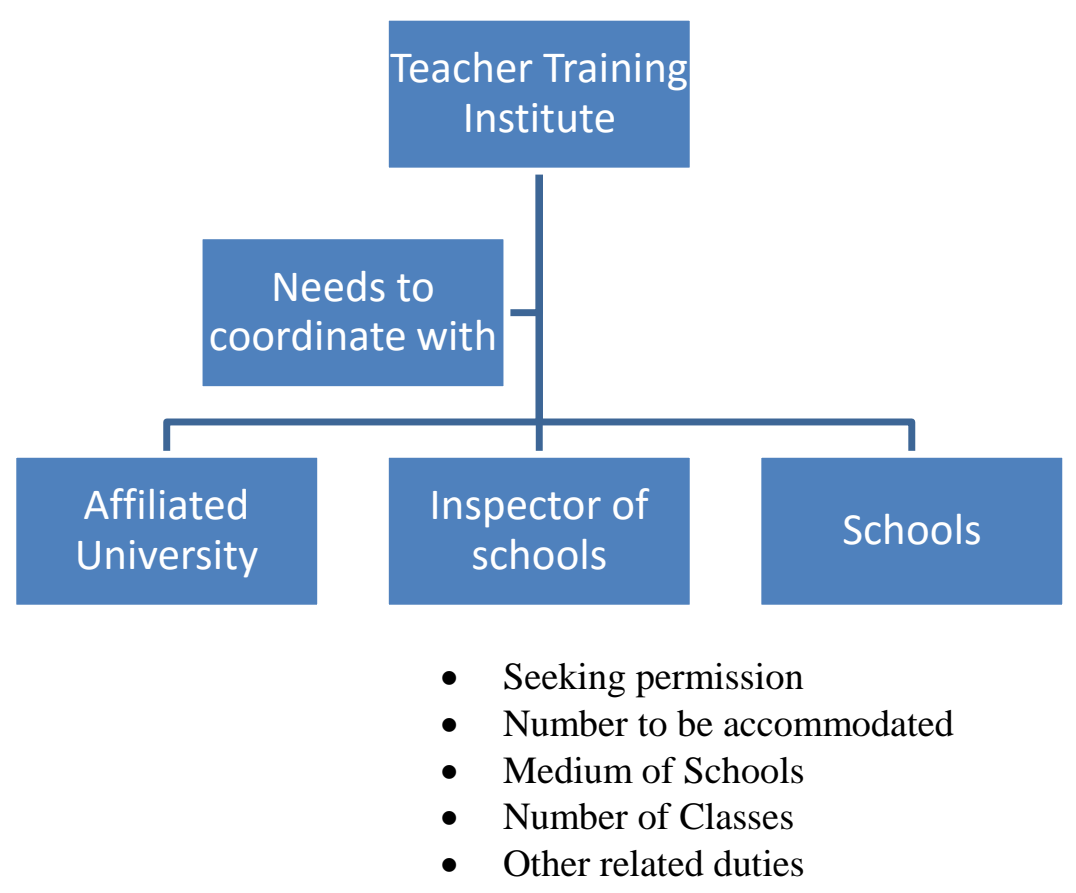

Fig.1 Coordination for Internship Program

In the internship program student teachers must perform day to day activities as directed by the head of the schools. The activities carried out have to be recorded in a diary and at the end of each month they must furnish in report form. An outline of the report format is framed as shown in Table 2. The report should bear a clear picture of the activities both academic as well as co-curricular activities along with a brief general information about the school conducted during the intern period. The aim, purpose and utility of Internship program has to be clearly spelt out to the student teachers. The format is sure to assist the student teachers in planning and implementing their activities. 
Table 2 Outline of Monthly Report Format

\begin{tabular}{|ll}
\hline First month) & \\
General Information & \\
Name of the School $:$ & \\
Address & $:$ \\
Location of School & $:$ Rural/Urban /Semi-Urban \\
Timing of School & $:$ From ...... to ....... \\
Classes & $:$ From ....... to ........
\end{tabular}

Medium of Instruction:

Type of School : Boys/Girls/Coeducational

Name of Principal/Headmaster/Headmistress:

Employees Information:

Number of Teaching Staff-

Number of Non - Teaching Staff-

Type of building : Assam type/R.C.C./Bamboo/any other ....................

No. of Class Rooms -

Observation activity :

Relation to students -

Classroom facilities -

School campus -

Break time behaviour and activity of students -

Infrastructure facilities

No. of Rooms -

Room Name

Dustbin -

Fire extinguisher -

Playground availability and maintenance -

Library Facility :

No. of books -

No. of Newspaper/Journals/Magazines -

Laboratories :

Computer Laboratory -

Science Laboratory -

Notice Board System :

Co-curricular Facilities 


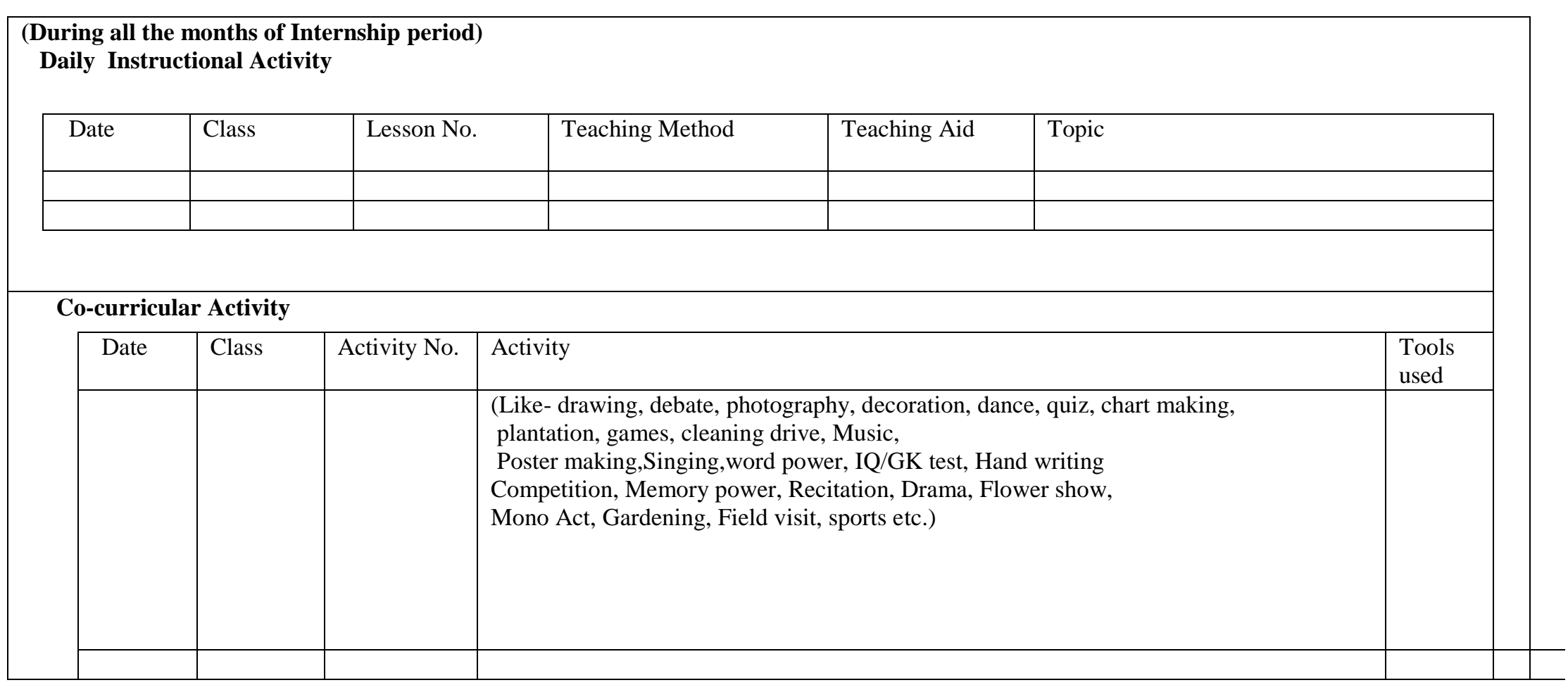


Evaluation System :

No. of Test undertaken -

Class test/Weekly test/Once a month test -

Type of Question Paper - Self prepared/Previous school question paper/Board question paper-

Academic Performance sheet -

\begin{tabular}{|l|l|l|l|l|}
\hline Roll No. & Name of Student & Sex & Marks obtained & Grade/ Remarks \\
\cline { 3 - 4 } & & $\begin{array}{l}\text { Subject(s) taught -English/MIL/Maths/Env. Sc./ } \\
\text { Soc. Sc. /Additional subject }\end{array}$ & \\
\hline
\end{tabular}

Co-curricular Performance sheet -

\begin{tabular}{|l|l|l|l|l|}
\hline Roll No. & Name of Student & \multirow{2}{*}{ Sex } & Marks obtained & Grade/ Remarks \\
\cline { 4 - 5 } & & & & \\
\hline & & & & \\
& & & & \\
\hline
\end{tabular}

Internship Experience :

Acknowledgement :

(Format prepared by Dr.P.Chakrabarty, 2016) 
The task of Teacher Supervisor/Mentor is to assess the student teachers activities along with the guidance to be offered. The Teacher Supervisor shall evaluate the diaries of the student teachers from time to time. The roles of Teacher Supervisor and student teachers are illustrated in figure 2.

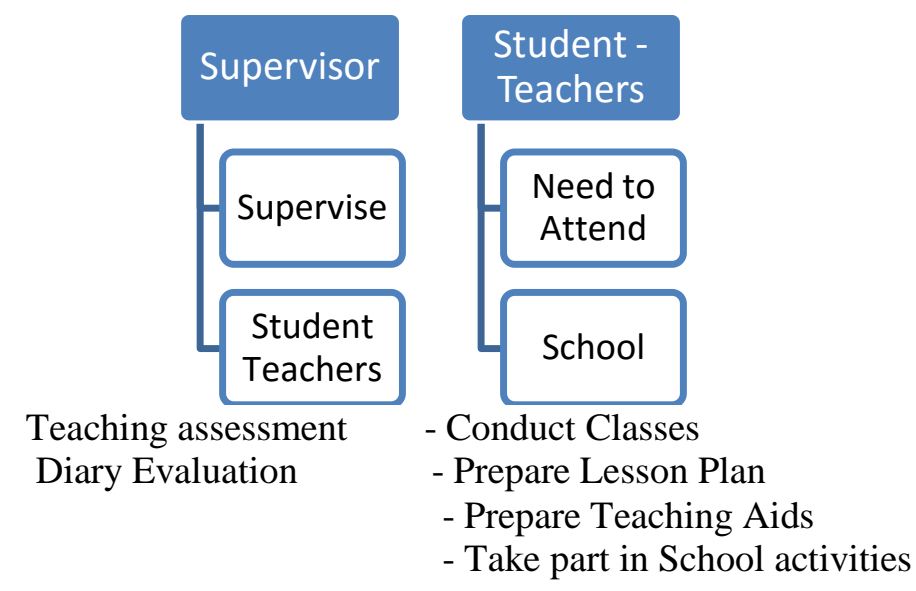

Fig. 2 Role of Teacher Supervisor and student teachers during Internship

\section{$\underline{\text { References : }}$}

Principal, Victoria College of Education Bhopal (2015) The Study of Teaching Attitude of B.ed Trainee Teacher Before and their Internship, Indian Journal of Applied Research, Volume : 5, Issue : 12, December, ISSN - 2249-555X

Varia, Vishal S. (2012). M.Ed. Internship ReportA.Y. 2011 - 2012, Education Department, Saurashtra University, Rajkot

http://www.macrothink.org/journal/index.php/ijld/article/download/1471/1186

http://www.academia.edu/4564980/Sample_Internship_Report_useful_for_M.Ed._St $\underline{\text { udents }}$

http://www.worldwidejournals.com/ijar/file.php\%3Fval\%3DDecember_2015_14507 03739_20.pdf

http://ro.ecu.edu.au/cgi/viewcontent.cgi\%3Farticle\%3D1147\%26context\%3Dajte

http://uir.unisa.ac.za/bitstream/handle/10500/10502/dissertation hendrikse jv.pdf\%3 Fsequence\%3D1

\section{http://www.aiaer.net/ejournal/vol19107/10.htm}

\section{http://ncte-india.org/Curriculum\%2520Framework/B.Ed\%2520Curriculum.pdf}

file:///H:/EXTENDING\%20BACHELOR\%20OF\%20EDUCATION\%20PROGRAM

ME.html 